\title{
ENRAIZAMENTO in vitro DE MUDAS MICROPROPAGADAS DE BANANEIRA (Musa sp.) EM DIFERENTES MEIOS DE CULTIVO
}

\author{
In vitro rooting of micropropagated banana tree (Musa sp.) seedlings in different culture media
}

\author{
Mara Rubia Camolesi ${ }^{1}$, Adriana Novais Martins ${ }^{2}$, Lara Daniela de Souza ${ }^{3}$, Cibelle Garcia Saconi ${ }^{4}$
}

\begin{abstract}
RESUMO
Objetivou-se, neste trabalho, avaliar o processo de enraizamento in vitro de mudas micropropagadas das cultivares de bananeira (Musa sp.) ‘Nanicão Jangada' (AAA), 'Nanicão Grande Naine’ (AAA) e 'Maçã' (AAB) utilizando-se os meios de cultivo semissólido e líquido. Foram utilizadas mudas micropropagadas oriundas de meristemas retirados de mudas do tipo chifrinho coletadas em bananais comerciais na Região do Médio Paranapanema, estado de São Paulo. Foram constituídos dois tratamentos sendo: meio líquido, sem a adição de agente gelificante e meio semissólido, gelificado com $7 \mathrm{~g} \mathrm{~L}^{-1}$ de ágar. O delineamento estatístico utilizado foi o inteiramente casualizado, sendo que cada tratamento foi constituído por 30 frascos, contendo 6 mudas/frasco. Após 30 dias, as plântulas foram retiradas dos frascos e foram avaliados os seguintes parâmetros: comprimento da maior raiz, número total de raízes, número total de folhas e altura da parte aérea. Foram avaliadas 50 plântulas por tratamento. Os resultados obtidos demonstraram que as 3 cultivares avaliadas apresentaram melhor desenvolvimento radicular em meio semissólido, entretanto, o número de raízes foi maior em meio líquido, principalmente para a cultivar 'Maçã'. O número total de folhas por plântula foi maior, de modo geral, no meio semissólido, enquanto que a altura das plântulas foi maior no meio líquido. A cultivar 'Maçã’ apresentou as maiores diferenças entre os meios semissólido e líquido em todos os parâmetros avaliados.
\end{abstract}

Termos para indexação: Micropropagação, cultivares, sistema radicular.

\section{ABSTRACT}

The objective of this study was to evaluate the process of in vitro rooting of micropropagated seedlings of 'Nanicão Jangada' (AAA), 'Nanicão Grande Naine' (AAA) and 'Maçã' (AAB) banana cultivars (Musa sp.) using semi-solid and liquid media. Plantlets originated from micropropagated meristems removed from seedlings collected in banana trade in the Médio Paranapanema region, State of São Paulo were used. Two treatments were tested: liquid medium without the addition of jelling agent and a semi-solid medium with $7 \mathrm{~g} \mathrm{~L}^{-1}$ agar. The statistical design was completely randomized, each treatment was set for 30 flasks containing 6 seedlings per flask. After 30 days, the seedlings were removed from flask, and the following parameters were assessed: length of the longest root, the total number of roots, the total number of leaves and plant height. Fifty seedlings were evaluated per treatment. The results demonstrate that the 3 cultivars evaluated showed better root development in semi-solid medium, however, the number of roots was higher in liquid medium, mostly for 'Maçã' cultivar. The total number of leaves per seedling was higher, generally in semisolid medium, while plant height was higher in liquid medium. The 'Maçã' cultivar presented the largest differences between the semisolid and liquid media in all parameters evaluated.

Index terms: Micropropagation, cultivars, root system.

\section{(Recebido em 24 de outubro de 2008 e aprovado em 17 de julho de 2009)}

\section{INTRODUÇÃO}

O Brasil produz cerca de 7 milhões de toneladas de banana por ano, em uma área de aproximadamente 505 mil hectares, sendo que São Paulo ocupa o segundo lugar em produção responsável por 15,5\% da produção nacional (Anuário da Agricultura Brasileira, 2008).

O método de propagação da bananeira é exclusivamente vegetativo. A utilização de mudas convencionais, por exemplo mudas de rizoma, contribui significativamente para a disseminação de pragas e doenças (Souza et al., 2000; Roels et al., 2005).
A cultura de tecidos ou micropropagação vem sendo muito utilizada como uma alternativa viável de propagação da cultura em grande escala, produzindo mudas de alto vigor vegetativo, em curto espaço de tempo e isentas de problemas fitossanitários (Kozai et al., 1997; Souza et al., 2000; Alves et al., 2004).

Várias técnicas estão sendo implementadas para minimizar os problemas de variação somaclonal, resultante de número excessivo de subcultivos realizados durante o processo de micropropagação (Israeli et al., 1996; Rodrigues et al., 1998; Álvares \& Caldas, 2002; Santos \& Rodrigues,

\footnotetext{
${ }^{1}$ Universidade Estadual de Londrina/UEL - Centro de Ciências Agrárias/CCA - Cx. P. 6001 - 86.051-990 - Londrina, PR - mrcamol@gmail.com ${ }^{2}$ Agência Paulista de Tecnologia dos Agronegócios/APTA - Assis, SP

3Universidade Estadual de Maringá/UEM - Maringá, PR

${ }^{4}$ Agência de Desenvolvimento Regional/BIOMAVALE - Assis, SP
}

Ciênc. agrotec., Lavras, v. 34, n. 6, p. 1446-1451, nov./dez., 2010 
2004), reduzir os custos da multiplicação in vitro (Kodym \& Zapata-Arias, 2001; Bernardi et al., 2004; Erig \& Schuch, 2005) e produção em alta escala, como no caso dos biorreatores em imersão temporária (Alvard et al., 1993; Lemos et al., 2001; Matsumoto \& Brandão, 2002; Colmenares \& Gimenez, 2003).

Entretanto, poucos são os resultados obtidos em relação ao enraizamento in vitro das mudas, o qual influencia diretamente no desempenho das mudas nas fases de aclimatização e plantio em condições de campo. Domingues et al. (1995) estudaram a utilização de ápices caulinares de bananeiras (cultivar Maçã) e o desempenho do enraizamento in vitro das plântulas utilizando meios líquido, semissólido e sólido; os autores observaram que a indução do enraizamento foi favorecida no tratamento em meio semissólido, com adição de AIB ou ANA e na ausência de citocinina. A fase de isolamento das plântulas e o enraizamento pode ser realizada em meio de cultura, desprovido de reguladores de crescimento, sendo que a utilização de menores concentrações de hormônios é um dos fatores que diminuem as taxas de variação somaclonal (Souza et al., 1999; Braga et al., 2001).

Em estudo mais recente, Costa et al. (2008) observaram que a indução do enraizamento in vitro em plântulas de bananeira, ocorre em até 14 dias de cultivo, sendo que após esse período houve apenas o crescimento em tamanho das raízes.

Vários trabalhos publicados sobre enraizamento de plântulas de bananeira micropropagadas dizem respeito à utilização de micorrizas na fase de aclimatização (ex vitro) das mudas (Matos et al., 2002; Lins et al., 2003; Trindade et al., 2003; Leal et al., 2005).

O enraizamento in vitro foi estudado em outras culturas, relacionado principalmente com o teor de sacarose do meio de cultivo, como trabalhos realizados com morangueiro (Calvete et al., 2002) e com porta-enxerto de videira (Villa et al., 2006).

Correia et al. (1995) relacionaram o efeito do meio de cultivo líquido e semissólido na multiplicação in vitro de clones de Eucalyptus grandis X Eucalyptus urophylla, identificando superioridade no crescimento e desenvolvimento de plântulas no meio semissólido. Costa et al. (2007) avaliaram agentes gelificantes alternativos em meio de cultura para cultivo in vitro de abacaxi e banana e concluíram que o meio líquido estacionário não aumenta a taxa de multiplicação da espécie.

Objetivou-se, neste trabalho, avaliar o processo de enraizamento in vitro, de mudas micropropagadas das cultivares de bananeira 'Nanicão Jangada' (AAA), 'Nanicão Grande Naine’ (AAA) e ‘Maçã’ (AAB), utilizandose meios de cultivo semissólido e líquido.

\section{MATERIAL E MÉTODOS}

O trabalho foi desenvolvido no "Laboratório de Cultivo in vitro de Espécies Ornamentais e Frutíferas” do BIOMAVALE - Sociedade Civil de Interesse Público, em Assis, SP. Foram utilizadas mudas micropropagadas oriundas de meristemas retirados de mudas do tipo chifrinho coletadas em bananais comerciais das cultivares 'Nanicão Jangada', 'Nanicão Grande Naine’ e 'Maçã', na Região do Médio Paranapanema, estado de São Paulo. Os meristemas foram estabelecidos in vitro em meio MS (Murashige \& Skoog, 1962) modificado com metade da concentração dos macronutrientes, acrescido de $30 \mathrm{~g} \mathrm{~L}^{-1}$ de sacarose e 1,0 $\mathrm{mg} \mathrm{L}^{-1}$ de BAP (6 benzilaminopurina), por 30 dias. Posteriormente, foram multiplicados por cinco subcultivos de um mês cada, no mesmo meio com 2,5 mg L $\mathrm{m}^{-1}$ de BAP (6 benzilaminopurina).

Os brotos micropropagados, foram individualizados e enraizados em frascos de $250 \mathrm{~mL}$ contendo $40 \mathrm{~mL}$ de meio MS com metade da concentração dos macronutrientes, acrescido de $30 \mathrm{~g} \mathrm{~L}^{-1}$ de sacarose e sem a adição de hormômios. Para o enraizamento foram constituídos dois tratamentos: meio líquido, sem a adição de agente gelificante e meio semissólido, gelificado com $7 \mathrm{~g} \mathrm{~L}^{-1}$ de ágar. $\mathrm{O}$ pH foi ajustado para 5,8 antes da autoclavagem. Após a inoculação, os frascos de cultivo foram acondicionados em sala de crescimento, sob temperatura de $25 \pm 2^{\circ} \mathrm{C}$, com fotoperíodo de 16 horas e irradiância de fótons de $50 \mu \mathrm{mol} \mathrm{m} \mathrm{m}^{-2} \mathrm{~s}^{-1}$, proporcionada por lâmpadas fluorescentes tipo luz do dia.

O delineamento estatístico utilizado foi o inteiramente casualizado, sendo que cada tratamento foi constituído por 30 frascos, contendo 6 mudas/frasco. Após 30 dias, as plântulas foram retiradas dos frascos, e foram avaliados os seguintes parâmetros: comprimento da maior raiz (CMR), número total de raízes (NR), número total de folhas (NF) e altura da parte aérea (APA). Foram avaliadas 50 plântulas por tratamento.

Os resultados foram submetidos às análises estatísticas de variância e de comparação de médias, por meio do Teste de Tukey, a 5\% de probabilidade, utilizandose o software estatístico SAS.

\section{RESULTADOSE DISCUSSÃO}

Foram observadas diferenças estatísticas em todos os parâmetros analisados, tanto em relação às cultivares, quanto para o tipo de meio de cultivo (Tabelas 1 e 2).

Em termos de comprimento da maior raiz das plântulas, pôde-se observar na Tabela 1, valores maiores para a cultivar 'Maçã', nas plântulas enraizadas em meio 
semissólido. Comparando-se o desempenho das três cultivares no meio semissólido nota-se que as plântulas da cultivar 'Maçã' apresentaram valores de comprimento da maior raiz 19,3\% e 18,3\% superiores às cultivares 'Nanicão Grande Naine' e 'Nanicão Jangada', respectivamente. A cultivar 'Maçã' apresentaram resposta inferior nesse parâmetro quando se comparou os dois meios de cultivo, sendo que plântulas dessa cultivar, enraizadas em meio líquido apresentaram redução de 16,6\% no comprimento da maior raiz, quando comparada ao meio semissólido.

De modo geral, as plântulas enraizadas em meio semissólido apresentaram maior crescimento radicular (média das cultivares de 11,58 cm), em relação às plântulas enraizadas em meio líquido (média das cultivares de 10,63cm). Somente a cultivar 'Nanicão Jangada' apresentou tendência de maior crescimento radicular no meio líquido, entretanto sem diferença estatística. De acordo com resultados obtidos por Costa et al. (2008), a indução radicular ocorre somente nos primeiros 14 dias, sendo que após esse período ocorre somente o crescimento em comprimento das raízes. Neste trabalho, o período de enraizamento foi de 30 dias o que pode ter induzido crescimento das raízes semelhante entre os tratamentos em cada tipo de meio avaliado.

Em relação ao número de raízes (Tabela 1) observase que a cultivar 'Maçã' apresentou comportamento inverso, ou seja, apesar de apresentar raízes de maior

Tabela 1 - Influência do tipo de meio de cultivo no enraizamento in vitro para comprimento da maior raíz (cm) e número de raízes de plântulas de bananeiras, cultivares ‘Nanicão Jangada’, 'Nanicão Grande Naine’ e ‘Maçã’. Assis, 2008.

\begin{tabular}{|c|c|c|c|c|}
\hline \multirow{2}{*}{ Meio de cultivo } & \multicolumn{3}{|c|}{ Cultivares } & \multirow{2}{*}{ C.V. (\%) } \\
\hline & 'Nanicão Jangada’ & 'Nanicão Grande Naine’ & 'Maçã' & \\
\hline \multicolumn{5}{|c|}{ Comprimento da maior raiz (cm) } \\
\hline Semissólido & $10,82 \mathrm{aB}$ & $10,69 \mathrm{aB}$ & $13,24 \mathrm{aA}$ & 23,5 \\
\hline Líquido & $11,40 \mathrm{aA}$ & $9,43 \mathrm{bB}$ & $11,05 \mathrm{bA}$ & 27,2 \\
\hline C.V. (\%) & 23,5 & 24,13 & 27,12 & \\
\hline \multicolumn{5}{|c|}{ Número total de raízes/plântula } \\
\hline Semissólido & $5,68 \mathrm{bA}$ & $5,86 \mathrm{aA}$ & $4,12 \mathrm{bB}$ & 29,2 \\
\hline Líquido & $6,32 \mathrm{aA}$ & 5,70 aA & $4,92 \mathrm{aB}$ & 24,7 \\
\hline C.V. (\%) & 22,57 & 25,95 & 23,67 & \\
\hline
\end{tabular}

Médias seguidas por letras distintas, minúsculas na vertical e maiúsculas na horizontal, diferem entre si pelo Teste de Tukey, a 5\% de probabilidade.

Tabela 2 - Influência do tipo de meio de cultivo no enraizamento in vitro para número de folhas e altura (cm) de plântulas de bananeiras, cultivares ‘Nanicão Jangada’, ‘Nanicão Grande Naine’e ‘Maçã'. Assis, 2008.

\begin{tabular}{|c|c|c|c|c|}
\hline \multirow{2}{*}{ Meio de cultivo } & \multicolumn{3}{|c|}{ Cultivares } & \multirow{2}{*}{ C.V. $(\%)$} \\
\hline & 'Nanicão Jangada' & 'N anicão Grande $\mathrm{N}$ aine' & 'Maçã' & \\
\hline \multicolumn{5}{|c|}{ Núm ero de folhas } \\
\hline Semissólido & $2,38 \mathrm{aB}$ & $2,74 \mathrm{aA}$ & $2,30 \mathrm{aB}$ & 25,3 \\
\hline Líquido & $2,44 \mathrm{aA}$ & $2,52 \mathrm{bA}$ & $1,98 \mathrm{bB}$ & 26,9 \\
\hline C.V. $(\%)$ & 27,8 & 21,1 & 23,2 & \\
\hline \multicolumn{5}{|c|}{ Altura (cm) } \\
\hline Semissólido & $3,78 \mathrm{aA}$ & $2,86 \mathrm{aB}$ & $2,94 \mathrm{bB}$ & 28,9 \\
\hline Líquido & 3,51 aA & $2,69 \mathrm{aB}$ & 3,45 aA & 22,8 \\
\hline C.V. $(\%)$ & 20,7 & 20,3 & 21,3 & \\
\hline
\end{tabular}

Médias seguidas por letras distintas, minúsculas na vertical e maiúsculas na horizontal, diferem entre si pelo Teste de Tukey, a 5\% de probabilidade.

Ciênc. agrotec., Lavras, v. 34, n. 6, p. 1446-1451, nov./dez., 2010 
comprimento, o número de raízes foi menor quando comparado com as outras duas cultivares. As plântulas enraizadas em meio líquido apresentaram ligeira superioridade $(7,6 \%)$ em termos de número de raízes, quando comparadas ao meio semissólido. Esse resultado já havia sido ressaltado em trabalho realizado por Rocha et al. (19--), com a cultivar 'Nanicão Grande Naine’. De acordo com Lins et al. (2003) plantas com bom desenvolvimento radicular no final do processo de micropropagação, tanto em termos de número como comprimento de raízes, resultam em plantas com sistema radicular mais consistente no processo de aclimatização.

O crescimento da parte aérea das plântulas, avaliado através do número total de folhas e altura (Tabela 2), mostrouse valores com diferentes estatisticamente em relação aos meios de cultivo para as cultivares 'Nanicão Grande Naine' e 'Maçã', sendo que essa diferença não foi encontrada para as plântulas da cultivar 'Nanicão Jangada'.

O número total de folhas por plântula apresentou tendência de redução no meio líquido. Na cultivar 'Nanicão Grande Naine’ apresentaram-se valores estatisticamente maiores no meio semisólido, entretanto muito próximos aos resultados obtidos nas cultivares 'Nanicão Jangada' e 'Maçã' (13,1\% e 16,1\%, respectivamente).

Em relação à altura das plântulas (Tabela 2), observou-se superioridade da cultivar 'Nanicão Jangada', não havendo diferença estatística na comparação dos meios. A cultivar 'Maçã' apresentou melhor desempenho em meio líquido, com acréscimo de 14,8\%, quando comparada ao meio semissólido. A cultivar 'Nanicão Grande Naine' foi a que apresentou o menor crescimento, diferindo estatisticamente das demais cultivares.

Alguns trabalhos encontrados na literatura relacionam o maior crescimento da parte aérea de plântulas micropropagadas de bananeira, em avaliações in vitro, com a composição nutricional do meio de cultivo, como no caso do trabalho realizado por Bernardi et al. (2004), que estudaram a micropropagação de bananeiras da cultivar 'Maçã', e Souza \& Gonçalves (1996), que formularam meios de cultivos específicos através de dados nutricionais para a cultivar 'Nanicão'. Costa et al. (2008) obtiveram indicações de que o crescimento das plântulas é diretamente proporcional ao tempo de permanência dessas plântulas no meio de cultivo.

\section{CONCLUSÕES}

As cultivares de bananeiras 'Nanicão Jangada', 'Nanicão Grande Naine' e 'Maçã' apresentaram melhor desenvolvimento radicular em meio semissólido, entretanto, o número de raízes foi maior em meio líquido.
A cultivar 'Maçã' foi a quê apresentou maiores valores de comprimento de raiz em meio semissólido.

O número total de folhas por plântula in vitro foi maior, de modo geral, no meio semissólido, enquanto que a altura das plântulas foi maior no meio líquido.

A cultivar 'Maçã' foi a que apresentou as maiores diferenças entre os meios semissólido e líquido em todos os parâmetros avaliados

\section{AGRADECIMENTOS}

Ao "Laboratório de Cultivo in vitro de Espécies Ornamentais e Frutíferas” da Agência de Desenvolvimento Regional BIOMAVALE, Assis, SP, pela disponibilização da estrutura laboratorial para a realização deste trabalho.

\section{REFERÊNCIAS BIBLIOGRÁFICAS}

ALVARD, D.; COTE, F.; TEISSON, C. Comparison of methods of liquid médium culture for banana micropropagation. Plant Cell, Tissue and Organ cultura, Dordrecht, v.32, p.55-60, 1993.

ÁLVARES, M.C.; CALDAS, L.S. Crescimento, produção e variação somaclonal em bananeiras micropropagadas. Pesquisa Agropecuária Brasileira, Brasília, v.37, p.415420, 2002.

ALVES, E.J.; LIMA, M.B.; SANTOS-SEREJO, J.A.; TRINDADE, A.V. Propagação. In: BORGES, A.L.; SOUZA, L.S. (Org.). A cultura da bananeira. Cruz das Almas: Embrapa, 2004. p.59-86.

ANUÁRIO DAAGRICULTURABRASILEIRA. Banana. São Paulo: Instituto FNP, 2008. 203p.

BERNARDI, W.F.; RODRIGUES, B.I.; CASSIERI NETO, P.; ANDO, A.; TULMANN NETO, A.; CERAVOLO, L.C.; MONTES, S.M.N.M. Micropropagação de baixo custo em bananeira cv. Maçã em meios com diferentes fontes de carbono e avaliação da performance em campo das mudas produzidas. Revista Brasileira de Fruticultura, Jaboticabal, v.26, n.3, p.503-506, 2004.

BRAGA, M.F.; SÁ, M.E.L.; MUSTAFÀ, P.C. Avaliação de um protocolo para multiplicação in vitro da bananeira (Musa sp.) cv. Caipira (AAA). Revista Brasileira de Fruticultura, Jaboticabal, v.23, n.2, p.215-219, 2001.

CALVETE, E.O.; KÄMPF, A.N.; SUZIN, M. Concentração de sacarose no enraizamento in vitro do morangueiro. Horticultura Brasileira, Brasília, v.20, n.2, p.196-191, 2002. 
COLMENARES, M.; GIMENEZ, C. Multiplicación in vitro Musa spp. mediante sistema de inmersión temporal. Revista da Faculdade Agrária, Caracas, v.20, n.4, p.468477, 2003.

CORREIA, D.; GONÇALVES,A.N.; COUTO, H.T.Z.; RIBEIRO, M.C. Efeito do meio de cultura líquido e sólido no crescimento e desenvolvimento de gemas de Eucalyptus grandis X Eucalyptus urophyllana multiplicação in vitro. IPEF, Piracicaba, n.48/49, p.107-116, 1995.

COSTA F.H.S.; PASQUAL, M.; PEREIRA, J.E.S.; RODRIGUES, F.A.; MIYATA, L.Y. Relação entre o tempo de enraizamento in vitro e o crescimento de plantas de bananeira na aclimatização. Revista Brasileira de Fruticultura, Jaboticabal, v.30, n.1, p.31-37, 2008.

COSTA, F.H.S.; PEREIRA, M.A.A.; OLIVEIRA, J.P.O.; PEREIRA, J.E.S. Efeito de agentes geleificantes alternativos no meio de cultura no cultivo in vitro de abacaxizeiro e bananeira. Ciência e Agrotecnologia, Lavras, v.31, n.1, p.41-46. 2007.

DOMINGUES, E.T.; TULMANN NETO,A.; MENDES, B.M.J. Cultura de ápices caulinares de Musa sp. var. Maçã: estabelecimento, micropropagação e enraizamento in vitro. Scientia Agricolae, Piracicaba, v.52, n.2, p.387394, 1995.

ERIG, A.C.; SCHUCH, M.W. Micropropagação fotoautotrófica e uso da luz natural. Ciência Rural, Santa Maria, v.35, p.961-965, 2005.

ISRAELI, Y.; BEN-BASSAT, D.; REUVENI, O. Selection of stable banana clones wich do not produce dwarf somaclonal variants during in vitro culture. Scientia Horticulturae, Amsterdam, v.67, p.197-205, 1996.

KODYM, A.; ZAPATA-ARIAS, F.J. Low-cost alternatives for the micropropagation of banana. Plant Cell Tissue and Organ Culture, Dordrecht, v.66, p.6771, 2001.

KOZAI, T.; KUBOTA, C.; BYOUNG, R.J. Environmental control for the large scale production of plants through in vitro techniques. Plant Cell Tissue and Organ Culture, Dordrecht, v.51, p.49-56, 1997.

LEAL, P.L.; MARTINS, M.A.; RODRIGUES, L.A.; SCHIAVO, J.A. Crescimento de mudas micropropagadas de bananeira micorrizadas em diferentes recipientes. Revista Brasileira de Fruticultura, Jaboticabal, v.27, n.1, p.84-87, 2005.

LEMOS, E.E.P.; FERREIRA, M.S.; ALENCAR, L.M.C.; OLIVEIRA, J.G.L.; MAGALHÃES, V.S. Micropropagação de clones de banana cv. Terra em biorreator de imersão temporária. Revista Brasileira de Fruticultura, Jaboticabal, v.23, n.3, p.482-487, 2001.

LINS, G.M. de L.; TRINDADE, A.V.; ROCHA, H.S. Utilização de Gigaspora margarita em plantas micropropagadas de bananeira em diferentes estádios de enraizamento. Revista Brasileira de Fruticultura, Jaboticabal, v.25, n.1, p.143-147, 2003.

MATOS, R.M.B.; SILVA, E.M.R.; BRASIL, F.C. Micorriza arbuscular e matéria orgânica na aclimatização de mudas de bananeira, cultivar Nanicão. Bragantia, Campinas, v.61, n.3, p.277-283, 2002.

MATSUMOTO, K.; BRANDÃO, A.K.C. Comparison of temporary and permanent immersion systems for the in vitro culture of banana. INFOMUSA, Montpellier, v.11, n.2, p.36-37, 2002.

MURASHIGE, T.; SKOOG, F. A revised medium for rapid growth and bioassays with tabacco tissue culture.

Physiologia Plantarum, Copenhagen, v.5, n.4, p.473-497, 1962.

ROCHA, B.A.M.; SANTIAGO, C.A.; GOMES, L.; CORREIA, D.; CAVALCANTE JÚNIOR, A.T. Efeito do acréscimo de meio líquido na multiplicação in vitro de gemas de bananeira, cv Grande Naine. Fortaleza: EMBRAPA Agroindústria Tropical, [19-]. 10p.

RODRIGUES, P.H.V.; TULMANN NETO, A.; CASSIERI NETO, P.; MENDES, B.M.J. Influência do número de subcultivos na ocorrência de variação somaclonal em mudas micropropagadas de bananeira 'Nanicão', no vale do Ribeira, SP. Revista Brasileira de Fruticultura, Cruz das Almas, v.20, p.74-79, 1998.

ROELS, S.; ESCALONA, M.; CEJAS, I.; NOCEDA, C.; RODRIGUEZ, R.; CANAL, M.J.; SANDOVAL, J.; DEBERGH, P. Optimization of plantain (Musa AAB) micropropagation by tempory immersion system. Plant Cell, Tissue and Organ cultura, Dordrecht, v.82, p.5766, 2005. 
SANTOS, C.C.C.; RODRIGUES, P.H.V. Variação somaclonal em mudas micropropagadas de bananeira, cultivar Pacovan. Bragantia, Campinas, v.63, n.2, p.201-205, 2004.

SOUZA, A. da S.; CORDEIRO, Z.J.M.; TRINDADE, A.V. Produção demudas. In: CORDEIRO, Z.J.M. Banana Produção: aspectos técnicos. Brasília: Embrapa Comunicação para Transferência de Tecnologia, 2000. p.39-46.

SOUZA, A. da S.; DANTAS, J.L.L.; SOUZA, F.V.D.; CORDEIRO, Z.J.M.; SILVA NETO, S.P. Propagação. In: ALVES, E.J. A cultura da banana: aspectos técnicos, socioeconômicos e agroindustriais. 2.ed. Brasília: Embrapa-SPI, 1999. p.151-195.
SOUZA, G.M.; GONÇALVES, A.N. Otimização de meio de cultura para bananeira (Musa cavendishii L.). Scientia Agricola, Piracicaba, v.53, n.1, 1996.

TRINDADE, A.V.; LINS, G.M.L.; MAIA, I.C.S. Substratos e fungo micorrízico arbuscular em mudas micropropagadas de bananeira na fase de aclimatação. Revista Brasileira de Fruticultura, Jaboticabal, v.25, n.1, p.137-142, 2003.

VILLA, F.; PASQUAL, M.; PIO, L.A.S.; ASSIS, F.A. Multiplicação in vitro de porta enxerto de videira em variações do meio MS. Acta Scientia Agronomy, Maringá, v.8, n.3, p.345-349, 2006. 